\title{
OS INTELECTUAIS E A REVOLUÇÃO
}

Francisco Máuri de Carvalho Freitas

Universidade Federal do Espírito Santo.

\section{RESUMO}

O tema do presente artigo, de permanente atualidade, notadamente por abordar a relação entre o intelectual e a revolução como método histórico incontornável de demolição da dominação do capital sobre o trabalho, ou seja, da burguesia sobre o proletariado. A base de estruturação do pensamento sobre os intelectuais, assim como a teoria da revolução, não está localizada nos homens e mulheres pensados, imaginados ou idealizados; mas homens e mulheres reais a partir de seu processo de vida real, o desenvolvimento do modo de produção da existência. Neste sentido, tive o cuidado de não cair na ilusão de conceber o real como resultado do pensamento. Para além do senso comum, o intelectual é produto histórico da sociedade despedaçada, testemunha que interiorizou esse despedaçamento. Enfim, o intelectual é o tipo de pessoa que se mete no que não é de sua conta e contesta o conjunto das verdades recebidas, e das condutas que nelas se inspiram, em nome de uma concepção global do homem e da sociedade. Por outro lado, compreendida como o protesto violento do homem trabalhador contra a desumanização de sua vida, a revolução ao dissolver a velha sociedade, é a alma política que ao derrotar o poder existente dissolve as velhas relações de produção e sem ela não é possível realizar o socialismo. A apologia da revolução ocorrendo por meios pacíficos é política e historicamente um engodo para a classe operária, em outras palavras representa o véu místico atrás do qual se esconde a vontade de usufruto de todos os hipócritas, a desculpa que mascara a torpeza das ignomínias do capitalismo e fonte de numerosos desregramentos da sociedade contemporânea. Palavras-chave: Contradição, falso intelectual, educação política, trabalho alienado, comunismo.

\section{RESUME}

\section{LES INTELLECTUELS ET LA RÉVOLUTION}

Le thème de cet article, poursuit aujourd'hui, notamment en abordant la relation entre l'histoire intellectuelle et de la révolution comme une méthodede domination de démolition inévitable du capital sur le travail, c'est à dire la bourgeoisie sur le prolétariat. La base pour structurer la réflexion sur les intellectuels ainsi que la théorie de la révolution, ne se trouve pas dans les hommes et les femmes ont pensé, imaginé ou idéalisée, mais de vrais hommes et femmes de leur processus de vie réelle, le développement de la production biologique l'existence. En ce sens, je faisais attention à ne pas tomber dans l'illusion de concevoir le réel comme un résultat de la pensée. Ainsi que le sens, l'intellectuel est le produit historique de la société déchirée, témoin qui a intériorisé cette rupture. Enfin, l'intellectuel est le genre de personne qui se met en n'est pas votre propre ensemble de défisles vérités reçues, et des comportements qui sont inspirés par eux au nomd'une conception globale de l'homme et la société. D'autre part, entendu comme la protestation violente de l'ouvrier contre la déshumanisation de sa vie, la révolution en dissolvant l'ancienne société, l'âme politique qui en battant le pouvoir existant dissout les vieux rapports de production et sansqu'il n'est pas possible le socialisme. L'éloge de la révolution en cours par des moyens pacifiques est politiquement et historiquement une moqueriede la classe ouvrière, en d'autres termes est le voile mystique derrière lequel se cache le désir d'être apprécié par tous les hypocrites, l'excuse queles masques de la laideur de l'ignominie du capitalisme et la source denombreux excès de la société contemporaine.

Mots-clés: Contradiction, faux intellectuel, l'éducation politique, du travail aliéné, le communisme. 


\section{Exórdios}

Na obra do filósofo brasileiro Roland Corbisier (1980) o homem é um ser que pergunta. Atacado pela dúvida pergunta, mas o faz, grosso modo, sem refletir sobre o próprio perguntar, sem indagar sobre o significado dessa operação da inteligência que se acha na raiz do conhecimento filosófico e do conhecimento científico. E ao perguntar, converte essa operação, aparentemente tão banal, tão quotidiana, em tema filosófico, da crítica radical.

E por que o homem precisa perguntar? A rigor, ele não sabe, não conhece, mas precisa saber, conhecer o mundo em que se encontra e no viverá por algum tempo. E para poder viver, conviver, com a realidade à sua volta, as coisas e os outros homens, precisa saber como as coisas e, sobretudo, os outros homens se comportam. Sem esse conhecimento não poderá orientar sua conduta em relação às coisas e aos homens. Sem embargo, para o homem o conhecimento por não ser facultativo, deve ser considerado como indispensável, vez que a sobrevivência do ser humano dele depende. Para que o conhecimento seja realmente útil e permita ao homem transformar a natureza, colocando-a a seu serviço, cuja ação transforma sua própria natureza, pela educação e pela cultura esse conhecimento transcende os estreitos limites do meramente empírico.

Aprendemos com esse filósofo que na origem do conhecimento está a necessidade de perguntar, de indagar, o que são as coisas e o que é o homem. E se o homem é a raiz do homem, então, pergunto porque não sei, ignoro o que pretendo ou preciso saber, sem esquecer, pari passu, a consciência dessa ignorância, o oco daquilo que desconheço e preciso conhecer. A mola deste processo, como não poderia deixar de ser é a contradição que atacava Sócrates, ou seja, ignoro e sei que ignoro. Em outras palavras, não sei e sei que não sei, e a ciência da insciência, consciência da ignorância é o que permite ao homem perguntar, à natureza e/ou aos outros homens.

A ruptura, a cisão, a contradição está na origem ou na raiz do ato de perguntar. Não sei, mas preciso saber e porque sei que não sei, pergunto, na expectativa de que a resposta possa trazer-me o conhecimento que não tenho e preciso ter. Neste sentido, destaquei da obra do autor estudado, Roland Corbisier (1980), um instigante livro é dedicado à memória de Lenin, filósofo e político teórico e prático da primeira revolução socialista, intitulado os "Intelectuais e a Revolução". E qual a causa ou qual motivo do destaque, do recorte?

É simples! A contradição socrática ergue-se majestosa, ignoro e sei que ignoro, ou seja, não sei sobre os intelectuais e a revolução o que gostaria e deveria de saber. A ciência desta insciência, ou a consciência de minha própria ignorância é a mola que me impulsiona perguntar sobre a natureza da revolução e o que são os intelectuais, qual seu compromisso histórico, qual sua missão política e para quem trabalham.

No livro sub examine o autor, como dito antes, se debruça sobre a questão dos intelectuais enquanto componente de todas as sociedades de classes onde o trabalho braçal é discriminado pelos donos dos meios de produção e pelos próprios intelectuais por ser este peculiar à classe operária, escravos e servos, enquanto o trabalho intelectual é pertença da classe dominante. Por não trabalhar, quer dizer, por não prover com seu próprio trabalho a sua subsistência, posto que outros o fazem por ele, o escravocrata, o senhor medieval e o burguês, podem entregar-se ao otium cum dignitatis. No transcurso da história da humanidade para as classes dominantes o trabalho era / é considerado aviltante, portanto incompatível com o estatuto da nobreza. Curiosamente o escravocrata e o nobre, grosso modo, não sabiam ler e nem escrever.

Contrariando o senso comum dos intelectuais, é possível dizer não existir “[...] trabalho, por mais tosco e rudimentar que seja que não envolva a participação da 
inteligência, quer dizer, a consciência dos fins e dos meios adequados à sua realização." (CORBISIER, 1980, p. 15). Para Corbisier,

O trabalho chamado intelectual, por sua vez, jamais é puramente intelectual, porque, não sendo espírito puro, como os anjos da imaginação religiosa, mas, ao contrário, espírito impuro, encarnado na matéria, ou melhor, matéria espiritualizada, da qual é tributário, o homem sempre pensa por meio do cérebro, órgão físico, de cuja sanidade depende, aliás, a possibilidade do pensamento. (...) Todo trabalho é, portanto, intelectual e manual, ao mesmo tempo, uma vez que não pensamos nem mesmo com o cérebro apenas, mas com o corpo todo, condição de possibilidade e funcionamento do cérebro. (CORBISIER, 1980, p. 17).

A negação da intelectualização política dos trabalhadores é, por certo, reflexo da deserção dos intelectuais da luta pela construção da sociedade justa e igualitária, a sociedade comunista, e da sua capitulação à direita e apostasia, isto é, a troca da teoria revolucionária, sem a qual não há movimento revolucionário, pela teoria reacionária necessária a manutenção da burguesia com o domínio sobre os meios de produção.

A questão dos intelectuais, como aponta o preclaro filósofo precisa ser enfrentada considerando-se que a cidade do capital, cidade da separação consumada, está cindida em duas, a cidade dos ricos e a cidadela dos pobres, separadas pelo muro da ignorância cuja garantia radica no aparato de repressão. Na cidade do capital a imagem prepondera sobre o concreto, a cópia se sobrepõe ao original, a representação ofusca a realidade, a aparência substitui o ser.

Nesta cidade, pensando com Feuerbach, os intelectuais orgânicos da classe dominante predicam a ilusão como sagrada, e a verdade como profanação da vida. Aos seus olhos o sagrado aumenta à medida que a verdade decresce e a ilusão cresce. Para eles, o cúmulo da ilusão é o cúmulo do sagrado. (FEUERBACH, 1986).

\section{Sobre o intelectual}

Postas as exordiais, convém registrar que para escrever sobre os intelectuais, na base da estruturação do pensamento não estão os homens e as mulheres pensadas, imaginadas, idealizadas, mas homens e mulheres reais em seu processo de vida real, ou seja, o modo de produção da existência por eles construído. Não se trata, portanto, de uma abordagem sobre os intelectuais a partir da fundamentação dogmática de quaisquer autores, mas de explicar essas teorias produzidas por intelectuais orgânicos de uma ou de outra classe social. Neste caso, dedico um necessário cuidado para não cair na ilusão de conceber o real "como resultado do pensamento, que se encontra em si mesmo, se aproxima em si mesmo e se movimenta por si mesmo." (MARX, 1983, p. 219).

Centrado no tema "Os intelectuais e a Revolução", devo registrar que o labirinto conceitual gramsciano no qual todos os homens e mulheres aparecem como intelectuais, é corroborado pelas afirmações de Sartre (1994) segundo as quais o intelectual é aquele que toma consciência da oposição, nele e na sociedade, por vezes, entre ele e a sociedade, entre a pesquisa prática com todas as normas que ela implica e a ideologia dominante com seu sistema de valores tradicionais. Para Sartre, o intelectual é produto da sociedade despedaçada, "[...] é sua testemunha porque interiorizou seu despedaçamento. É, portanto, um produto histórico." (SARTRE, 1994, p. 30). Sustentando a ironia sartreana como antecâmara da crítica ácida de Roland Corbisier, o intelectual é aquele "alguém que se mete no que não é de sua conta e que pretende contestar o conjunto das verdades recebidas, e das condutas que nelas se inspiram, em nome de uma concepção global do homem e da sociedade." (SARTRE, 1994, p. 14). 
Para Corbisier (1980, p.18), “[...] o intelectual, em estado potencial, é todo homem, pelo simples fato de ser humano, quer dizer, inteligente”. O intelectual é o indivíduo detentor de um conjunto de qualidades intelectivas e empíricas, históricas e socialmente estruturadas que o distinguem do não-intelectual, ou seja, aquele que nos seus afazeres diários usa predominantemente seu sistema muscular, em outras palavras, é aquele que utiliza predominantemente o trabalho braçal. A questão dos intelectuais é dotada de polissemia, pois:

Ao contrário dos cientistas, dos técnicos e dos artistas, enquanto tais, o intelectual é o não-especialista, o não-técnico, ou se quiserem, na formula que é um paradoxo, o especialista do universal. A rigor, o intelectual é o filósofo, que se define como já vimos, pelo projeto de aprender o real em sua totalidade, do ponto de vista sinóptico, como diria Platão. (CORBISIER, 1980, p. 18).

$\mathrm{Na}$ acepção mais ousada e realista, contrariando o senso comum acadêmico, o intelectual é o aquele a quem os capitalistas (industriais, banqueiros e latifundiários = classe dominante) atribuiu de fato e de direito a tarefa específica de elaborar e transmitir conhecimentos, teorias, doutrinas, ideologias, concepções de mundo ou simples opiniões, que acabam por constituir as ideias ou os sistemas de ideias de uma determinada época e de uma determinada sociedade. (BOBBIO, 1997). O intelectual por excelência, segundo Corbesier é o filósofo, isto é: "A consciência crítica da totalidade e, como a totalidade humana é a história, o intelectual enquanto filósofo é a consciência e a má consciência da história, o espírito crítico levado às últimas consequências, a infinita negatividade do espírito, como diria Hegel". (CORBISIER, 1980, p. 19).

O intelectual não produz coisas, objetos, apenas reflete sobre as coisas, objetos e fatos sociais, a rigor, ele não maneja instrumentos, objetos ou nem armas, aliás é um pacifista. O intelectual trabalha com símbolos, ou seja, ele é alguém cujos instrumentos de trabalho não são máquinas, mas ideias. A não ser que se considere que a máquina manipulada pelo intelectual seja um computador, rigorosamente não produzido por ele. Com outras palavras, o intelectual é um sujeito específico ou mais precisamente um conjunto de sujeitos específicos, considerados como criadores e transmissores de ideias. Coletivamente ele é o sujeito a quem o Estado e a classe dominante atribuiu à missão específica de elaborar e transformar teorias e ideologias ou simples opiniões, em ideias e sistemas de ideias da uma determinada sociedade que devem atender aos objetivos da classe dominante.

Convém precisar que ninguém é intelectual por direito natural ou por direito divino, na cidade do capital, onde ele vive, ocupa uma posição privilegiada, embora nem sempre reconheça que tal fato não é naturalmente reservado a ele e nem determinação de um demiurgo, o artesão divino, princípio organizador do universo ou designer do universo. $\mathrm{O}$ significado de intelectual está associado ao significado de inteligência, ou seja, do uso prevalente de operações mentais e de instrumentos da investigação com íntima relação com o desenvolvimento das ciências físico-químicas e da natureza.

Para o senso comum, a figura típica do intelectual, revelando-se por meio do exercício da palavra, está associada ao orador, ao retórico, ao demagogo, ao iluminado palrador, o sujeito que assumiu perante o Estado e a burguesia a missão de enganar os incautos. Quando age o faz normalmente nas assembleias e nas praças, sempre contra o povo e a favor do "príncipe". Ao ocultar a verdade reafirma o statu quo. Praticante da apostasia, jamais se engaja nos movimentos populares, preferindo viver um mundo a parte com os seus parelhos. 
O intelectual burguês, vez em quando, assume o papel de mediador, é arredio à luta de classe contra classe diante da qual acredita, sobremaneira, que sua missão enquanto tal seja a de não se comprometer com nenhuma das classes, além de observar com aristocrático desdém a gentalha se pegando a dentadas; especula e prognostica as desventuras das batalhas sempre em desfavor da classe operária. A virtude essencial desse tipo de intelectual é a tolerância que jamais se esgota.

A figura do intelectual na cidade do capital é emblemática. Apologista da liberdade de crítica, paradoxalmente, retira-se para a zona árida entre quatro paredes, com precipitações intelectuais escassas, compreensão inexistente ou rara sobre a lógica das coisas formadas pela dinâmica da estrutura capitalista. Portanto, diante da liberdade formal, tolera os coveiros da própria liberdade.

O intelectual orgânico da burguesia ou que a ela se vincularam pela prática da apostasia submete tudo à discussão, inclusive os princípios fundamentais da democracia como se fosse um mecanismo dotado de vida própria sobre o qual pouco ou nada se pode fazer. O espírito de conciliação tão peculiar aos intelectuais é a marca dos "amigos" da liberdade, igualdade, fraternidade e democracia.

Adepto da independência política e da neutralidade partidária, para além da indiferença ou da neutralidade perante a realidade objetiva, diante da injustiça, da mentira e da opressão, o intelectual, o verdadeiro e não o seu pasticho tem por dever ir à praça pública para assumir uma posição intransigente em defesa, exclusivamente, dos valores republicanos conquistados pelo povo nas batalhas urbanas e rurais, mas atraiçoados pela burguesa.

Contrariando os intelectuais que se consideram acima da patuleia se pegando a dentadas, devo dizer, que se sou obrigado a compreender tudo e não ter raiva de nada me torno o pai eterno: o que, além de tudo, não é sequer a minha tarefa.

Mas o que é realmente um intelectual? O intelectual tal como é predicado na cidade do capital é um ser bizarro de difícil classificação à medida que é recrutado nas várias camadas da população, tanto poder ser um pedótriba (escólio: do grego clássico, Paidotríbes era assim chamado o professor de ginástica para crianças), aristocrata, industrial, professor, artesão, operário, profissional liberal dentre outros.

Os intelectuais não constituem uma classe, formam uma categoria social, portanto, não se definem por seu lugar no processo de produção, mas por sua relação com as instâncias superestruturais ou extraeconômicas da estrutura social, especificamente pelo papel exercido no campo jurídico, político e ideológico. Lato sensu, reporta o estudioso supracitado:

Todo homem, na medida em que é inteligente, poderia ser considerado intelectual, pois não há trabalho, por mais tosco e rudimentar que seja, que não envolva a participação da inteligência, quer dizer, a consciência dois fins e dos meios adequados à sua realização. Nenhum trabalho, e o homem, como ensinam Hegel e Marx, é aquilo que faz, é o fruto e o resultado de seu trabalho, nenhum trabalho humano é puramente manual, quer dizer, mecânico e inconsciente. (...) só no homem a consciência dos fins é anterior à utilização dos meios que permitem realizá-lo. E, essa consciência, que caracteriza a atividade humana, por definição teleológica, não só está presente em todas as formas de trabalho, mas constitui sua primeira condição de possibilidade. (CORBISIER, 1980, p. 15)

Há nesta obra uma curiosidade sobre o intelectual no Medievo, que evidencia sua não neutralidade política, transcrita a seguir in totum: 
O nobre medieval não era um intelectual, os barões não sabiam ler, nem escrever, pois a cultura era monopólio da Igreja, e o intelectual, depositário da ciência da época, é o clérigo, o sacerdote, o religioso, representante do 'poder espiritual' que homologava e sacramentava o 'poder temporal' da nobreza hereditária. A vida intelectual, nos mosteiros, abadias e conventos, bem como nas 'escolas' e, mais tarde, nas Universidades, também implica a libertação das tarefas servis, o otium cum dignitatis, comum com a nobreza. É muito significativo que Tomás de Aquino, a maior figura da teologia cristã no século XIII, proclamado teólogo oficial da Igreja, seja um nobre, de família dos condes de Aquino, nascido no castelo de Rocaseca, perto do Nápoles. E não é menos significativo que, apesar de cristão, tenha feito, na Suma Teológica, a justificação do trabalho servil. (CORBISIER, 1980, p. 13-14).

Por outro lado, segundo a ortodoxia marxista, toda classe social que aspira chegar ao poder tem de prover seus próprios intelectuais, ponto de partida da crítica, sem deixar de considerar que todos os homens são intelectuais, embora nem todos os homens exerçam na sociedade o papel de intelectual. Os intelectuais, com raras exceções e em todos os tempos, vinculados as classes dominantes reforçam desejos e interesses históricos dessas classes, tornando-os universais e exercendo-se sobre os interesses e desejos da totalidade dos operários, servos e escravos.

\section{A contradição atual}

Outrora engajados na luta política pela transformação revolucionária deste país e do Continente sul-americano, os intelectuais, hoje, com raras exceções, se transformaram em pequenos funcionários da superestrutura ou técnicos do saber e, grosso modo, em intelectocratas (uma mistura bizarra e desagradável = intelectual + burocrata) estipendiados pela iniciativa privada, agrilhoados às alcandoras do Estado. Sectário positivista simpatiza no discurso com algumas teses do proletariado, enquanto na prática permanece na dependência da burguesia, não sabendo ou não querendo compreender que a revolução é a única via que conduz à humanidade à abolição do jugo do capital sobre o trabalho e libertar a humanidade do imperialismo. Por isto, cabe dizer que suas ideias não correspondem aos fatos, representam o acobertamento da objetividade perversa das sociedades capitalistas.

O ecletismo ideológico é a marca indelével da prática pedagógica política do intelectual. O ecletismo estacionário é uma clara afirmação da educação oficial como referendum do momento histórico brasileiro sob o slogan "país rico é país sem miséria", momento histórico de dependência e perda de soberania. O ecletismo permanece pleiteando a integração das diferentes concepções de mundo como se fossem mutuamente complementares e cujo resultado seria um todo compreensivo, contraponto ao sectarismo e dogmatismo. O ecletismo se propõe ser a concepção filosófica da totalidade, ou seja, procura estabelecer a confusão ideológica por intermédio dos "[...] seus ideólogos ativos, conceptivos, que fazem da formação de ilusões desta classe (a burguesia) a respeito de si mesma seu modo principal de subsistência." (MARX; ENGELS, 1979, p. 73).

Submersos no momento histórico brasileiro, seus sustentáculos no campo das ideias, o intelectual orgânico da burguesia e o falso intelectual de esquerda, descobriram as virtudes do livre mercado sem a intervenção do Estado (claro!), enquanto a grande maioria da população brasileira sofre suas consequências. (PETRAS, 1995). Mais ainda, ocultando que o neoliberalismo (ideologia do capitalismo no século XX) é o mais novo sinônimo da corrupção governamental e parlamentar generalizada, com o que resgatam o mito 
adormecido da colaboração de classes, derivado da perda da noção de conjunto e de totalidade.

Sem as posturas prevalentes desses intelectuais a classe dominante não consegue apresentar seus interesses como interesses comuns de todos os membros da sociedade, sendo que "[...] é obrigada a emprestar às suas ideias a forma de universalidade, a apresentá-las como sendo as únicas racionais, as únicas universalmente válidas." (MARX e ENGELS, 1979, p. 74). Negando a prática ou ação política como fundamento das teorias científicas e da própria filosofia, o intelectual se limita a contemplar com um suposto espírito crítico o mundo circundante e os acontecimentos que nele se desenrolam à sua revelia. Negando a ação revolucionária como mecanismo único de transformação da realidade objetiva, permanece no teorismo, na devoção e fascínio pelas teorias exóticas que afirmam a teoria e não a prática como força motriz da história. Negando o caráter revolucionário da ação histórica dos trabalhadores na transformação da sociedade capitalista, por caminhos diversos, controversos, mas não adversos, os intelectuais burgueses coadjuvam o projeto pedagógico político e histórico implantado neste país desde os anos setenta do século XX, com o qual a classe dominante procura obstar à classe trabalhadora o acesso aos conteúdos escolares básicos que, de certa forma, são imprescindíveis à vida dos seus filhos e filhas.

Esses mesmos intelectuais predicam que a ruptura real será produzida pela ruptura conceitual: a educação seria a salvação da Nação. Quiçá, sem saber, usam os mesmos e famosos argumentos usados nos famosos Pareceres de 1892 de Rui Barboza, para quem a educação era o único remédio para os males da sociedade brasileira.

A crítica levada às suas últimas consequências foi substituída por intermináveis discursos proferidos por de espantosos faladores, tagarelas de boca e de pena, virtuosos na arte de tergiversar, enganar e ludibriar. Sob o olhar do educador político, a educação brasileira é o espaço preferencial do falatório, da tagarelice, do compromisso desinteressado, da vaidade mórbida dos deformados narradores de cordel.

Notadamente os intelectuais da esquerda em retirada à direita esquecem que os capitalistas constroem a cidade do capital com a força do trabalho alienado, e a mais-valia dele extorquida, esse é o cenário do mundo capitalista convertido em prisão onde os trabalhadores, ainda alienados, têm que viver. Mundo sórdido que leva arrasta a miséria produzida pelo modo de produção capitalista da existência.

Este cenário não está acabado, mas nada nele é estável, como advogam uns e outros. A reformação permanente do espaço que nos envolve se justifica pela amnésia generalizada e pela insegurança na qual vivemos. Urge refazer tudo, a cidade do capital se torna cada dia mais suja e violenta; esta cidade é uma larga rodovia, racionalizada ao extremo, para facilitar sem sobressalto o transporte das mercadorias.

É exatamente neste mundo, estreito, funesto e lúgubre, onde o escravo moderno acumula mercadorias, renovadas, e riquezas que deveriam segundo o discurso oficial trazer-lhe a felicidade e o reino da liberdade. Porém ele não se dá conta, obnubilado pela mistificação da propaganda política que quanto mais acumula mercadorias, mais se afasta da felicidade e da liberdade.

Na contramão dos faladores é preciso colocar o sentido do embate, da polêmica, do ácido combate entre ideias antitéticas. Mas não é inteligente querer ser o detentor pessoal da verdade. Não há certezas pétreas, elas são historicamente construídas e não dadas $a$ priori. Neste quadro é preciso provocar, desafiar sempre comprometido com a verdade, concreta. Não afirmar, mas questionar, interrogar e replicar, eis a dimensão política da missão do educador político.

Não é possível negar o que não pode ser negado: as contradições sociais, materiais e econômicas, inerentes ao modo de produção capitalista da existência. Elas não são 
naturais, mas tornadas verdadeiros dogmas. Produzidas pela apropriação privada dos meios de produção, sobre elas põe-se a dúvida nem que seja por uma fração de segundo, à medida que elas não autorizam qualquer imbecil de má-fé a contestar peremptoriamente que o capitalismo é o destino inexorável da humanidade. Por exemplo, quando se fala da educação, notadamente do plano nacional de educação, dos avanços e retrocessos da economia política, me vem à mente Hegel, repito: se do mal nos livramos, o mal ficou, e ele é extraordinariamente mais forte, porque nele acreditamos sem suspeita, dúvida ou crítica.

É missão do intelectual vinculado às lutas populares de seu tempo, mostrar a realidade tal qual é na verdade e não tal como mostra o poder, isto constitui a mais autêntica subversão. Embora, lamentavelmente, ainda hoje permaneça a crença sem fundamento no suposto poder transformador das ideias, acredita-se que os aparatos conceituais são capazes de produzir o método necessário à demolição da República burguesa. Abstraídos da luta política da burguesia e do Estado capitalista contra o resto da população, os intelectuais da ordem "acreditam" e predicam a possibilidade de se chegar à sociedade alternativa por intermédio da educação.

Formulações desse calibre apenas demonstram desconhecimento da política, das teorias sociais, das concepções de mundo antitéticas e suas formulações teoréticas. Mais que dantes, permanecem como forças antagônicas nesta sociedade, de um lado, a burguesia industrial, financeira e fundiária, proprietários privados reais donos dos meios de produção, e, noutro flanco, os proletários, trabalhadores assalariados e os camponeses pobres, sem terra, desprovidos de qualquer propriedade, além da própria força de trabalho. Sem embargo, a possibilidade de construção do reino da liberdade sob o capitalismo, negação da liberdade, além de roubar a consciência proletária, enfraquece e confunde a consciência social, impedindo às novas gerações de perceber as contradições sociais e as desigualdades econômicas inerentes a ordem capitalista. Parafraseando Corbesier (1980), na estrutura do modo capitalista de produção da existência, caracterizada pela apropriação privada dos meios de produção material e intelectual (culturais), são os detentores do capital e os seus prepostos no governo central, regiamente pagos, aqueles que determinam e impõem o projeto pedagógico ou plano nacional de educação e os fins da educação nacional.

A missão da universidade pública é coadjuvar a formação da consciência social e não incutir dogmas e palavras de ordem que a burguesia tanto demanda. A atividade política, a luta pelo poder como meio de transformar a realidade, exige a crença absoluta na verdade, com o que se procura motivar a ação militante à resolução dos problemas. Neste caso, estamos diante de uma antinomia a superar:

As teorias pedagógicas, grosso modo, importadas e difundidas no interior da universidade, aplicadas nas escolas são baseadas na esperança e no medo (dois mecanismos de controle social muito bem manipulados pela classe dominante e seus cães de guarda). Essas teorias não colocam a dúvida como centro do processo de formação da consciência crítica e revolucionária. Portanto, não consideram a relação entre educação e política, enfim, desconsideram o robusto papel da educação no projeto de construção da sociedade socialista.

Obscura permanece a educação como condição e exercício de uma acurada compreensão crítica dos nexos e contradições em que estão inscritas a prática social do educador político, e a produção do conhecimento na indissociação da educação da política como crítica acerca da sociedade brasileira, uma sociedade despedaçada. Ainda é hora e tempo da reclamação incisiva por uma nova postura dos educadores, isto porque como diria Corbisier: 
Nous sommes embarqués, não só no sentido pascaliano da expressão, não só na aventura metafísica e dolorosa das nossas existências particulares, mas ainda e também na aventura maior e mais terrível das esperanças e das lutas da própria humanidade. Já não podemos pensar apenas em nós mesmos, já não temos o direito de recusar, por egoísmo ou covardia, a nossa participação e a nossa interferência nos negócios de nossa terra, evitando, por cálculo e conveniência, as palavras que possam ferir ou escandalizar as atitudes que possam abrir os nossos flancos, expondo-os à perfídia e ao ataque dos inimigos. (CORBISIER, 1956, p. 32).

Diante do medo à liberdade, medo sob o qual o humano se torna escravo e que congela a anima revolucionária existente em cada um de nós, o filósofo exclama: "Pouco importa que a nossa voz se perca, desfazendo-se no grande mar da indiferença e da incompreensão. Já vivemos o bastante [...] para saber que é sempre possível lutar, mesmo quando a tentação do desespero nos ronda, insistente, quase irresistível". (CORBISIER, 1980, p. 33).

As discussões sobre a educação brasileira e sua missão diante da Nação despedaçada, atacada em sua riqueza material e cultural por alienígenas de bandeira anglosaxônica imperialista, devem ter como propósito buscar soluções para a fome, a miséria, o desemprego, o fisiologismo, a corrupção e a violência, problemas indeléveis da cidade do capital. Essas discussões, encimado na crítica do Oráculo, devem recusar a inútil condição de tratar temas infecundos, de modo repetitivo, complacente e inconcludente, uma masturbatio ideológica entre as diversas correntes políticas partidárias e sindicais, desconectadas da realidade objetiva. Cabe à educação recusar o procedimento positivista de transladar mecanicamente métodos das ciências da natureza para as ciências sociais.

A consequência do enfoque positivista na educação é que interessa aos educadores estudar o ser humano apenas do ponto de vista biológico ou do ponto de vista sociológico, praticando a redução ao absurdo. Assim sendo é preciso superar a visão positivista das ciências sociais despojadas de juízos de valor, como as únicas capazes de produzir "verdades objetivas".

O ideal positivista produz deformações incontornáveis que servem às teorias sociais de reprodução do capital ou teorias crítico-reprodutivistas e à eliminação de qualquer teoria cujo teor seja crítico e revolucionário na análise das relações sociais de produção. A educação oficial ministrada na cidade do capital, não é educação política, na verdadeira acepção da palavra, à medida que não contém um programa político determinado, não revela convicções, não se exprime como disputa pelo poder e nem tem em seu bojo um contra Projeto de sociedade a ser edificada.

A educação oficial é possuída pela habilidade de acomodação ao estado de coisas do momento, se arrastando ante o governo federal e o Ministério da Educação, para cumprir ipsis litteris as ordens emanadas do Banco Mundial, tratando de se congraçar com o senso comum, a opinião pública. Essa educação na melhor das hipóteses está limitada a recolher pequenos feitos, supostamente interessantes, mal elaborados, sem cor e forma, e sobre os quais lança suspiros retóricos no lugar de aprofundar o estudo da filosofia e da política. Destarte, não estou a dizer que a educação oficial não seja útil, mas apenas que ela "não é política". (LENIN, t. 5, 1981, p. 358).

A educação política está calçada na realidade objetiva, vinculada aos interesses e demandas não da sociedade como um todo, mas da classe operária e dos trabalhadores assalariados do campo e das cidades. Por outro lado, a educação oficial, burguesa e capitalista, acontecendo no interior da escola oficial, pública ou privada, não é erigida sobre sólidos fundamentos filosóficos e ideológicos, elaborados por professores e 
professoras que pensam, querem e lutam pela construção de outro tipo de sociedade, sem classes e igualitária, só pode ser colocada em prática como tarefa de partido e sindicato.

Neste caso, um projeto de educação política não pode, pois, prescindir da propaganda das ideias iluministas, anarquistas, socialistas utópicas, comunistas e dos pensadores revolucionários do século XX. Ao contrário do pensado e apontado pelos intelectuais da ordem e pelos trânsfugas de todos os matizes, o aparelho ideológico de Estado escolar, em todas as suas dimensões, se mobiliza para desarticular a organização dos trabalhadores das cidades e do campo, e cujos objetivos são claramente obstar o avanço, para o cenário político, das forças sociais que já não podem ser ignoradas, e defender intransigentemente os privilégios da minoria parasitária.

Apesar da demagogia montada em torno da constituição democrática de um plano nacional de educação, convém salientar que os trabalhadores da educação não foram chamados a edificar o projeto pedagógico, pois sequer conseguem interferir na sua elaboração e "[...] na determinação dos seus fins, que não lhes são propostos, mas impostos, cabendo-lhes, apenas, realizá-los pelo seu trabalho." (CORBISIER, 1980, p. 21).

Semelhante ao trabalho alienado no processo econômico capitalista, no caso sob exame a característica do trabalho docente alienado consiste na não realização de um projeto político pedagógico próprio, mas na realização acrítica e servil de um projeto alheio, notadamente alienígena ou alóctone. $\mathrm{Na}$ atual conjuntura brasileira os professores desempenham de modo culposo ou doloso, o papel de instrumentos nas mãos dos donos, mercantilistas e mercadeiros da república.

Tal situação é agravada à medida que a universidade pública, gratuita, laica e de qualidade socialmente referenciada é tratada pelos capitães das indústrias e pelo próprio governo central como fábrica de produção de "cientistas" e técnicos dóceis indispensáveis ao capitalismo; e como mercado de ideias no qual a formação filosófica e humanista é substituída pela formação técnica e profissional. Atrelada ao mercado capitalista a educação prepara o "cientista" e o técnico que já têm à sua espera "[...] um função econômica e social que define a priori, como diz Sartre, "um homem abstrato, mas esperado'." (CORBISIER, 1980, p. 22).

Rigorosa, ontem e hoje, a análise de Roland, pertinente e atual, reporta que no Brasil a classe dominante, a proprietária dos meios de produção, determina não apenas o campo dos possíveis, mas, sobretudo, o campo do necessário, decidindo sobre o número de "cientistas" e técnicos, bem como sua remuneração, pois como os operários, são também assalariados. Negando-se a fazer política, ou negando a política como determinante, os quadros intelectualizados fazem o jogo político da direita, dos capitalistas, no qual prevalece o ensino oficial onde o capitalismo produz os funcionários da superestrutura, confinando-os, à maneira dos parafusos, aos "estreitos limites de suas funções." (CORBISIER, 1980, p. 22).

Outra questão é suscitada, se os interesses da classe dominante regulam a seleção dos "cientistas" e dos técnicos é fato que nessas categorias não existem operários, pois oriundos, notadamente, " "[...] da classe média (com raras exceções), não têm contato com a classe trabalhadora e convivem com o patronato, embora na relação de empregados e empregadores." (CORBISIER, 1980, p. 23). Ademais, por ocupar uma posição intermediária entre o capital e o trabalho, o estatuto econômico e social dessas categorias é o da ambiguidade. Esclareço. Assalariados, como os operários, os "cientistas" e os técnicos são cúmplices da sua exploração, vivendo, como os patrões, da mais valia.

A propósito, alguém poderá, certamente, argumentar que os "cientistas" e os técnicos são trabalhadores produtivos. Com efeito, encimado na analítica marxista é possível declarar que "[...] produtivo é o trabalhador que executa um trabalho produtivo e é produtivo o trabalho que gera diretamente mais valia, isto é, que valoriza o capital." 
(MARX, 1985, p. 109). Nesta quadra, Marx expõe que "um mestre-escola que ensina outras pessoas não é um trabalhador produtivo". Porém, um mestre-escola, ou um professor "[...] que é contratado com outros para valorizar, mediante o seu trabalho, o dinheiro do empresário da instituição que trafica com o conhecimento (mercadeiro da educação) é um trabalhador produtivo" (MARX, 1985, p. 116).

Quando o trabalhador com seu trabalho não produz capital, não gera mais-valia, diz-se ser ele um trabalhador improdutivo vivendo, pois a custa da mais-valia extorquida aos trabalhadores produtivos cujo trabalho constitui um elemento do processo de auto valorização do capital. Enquadrados no aparelho de produção capitalista, os "cientistas" e os técnicos "[...] sabem que o saber científico e tecnológico de que são portadores, universal, por definição, não está a serviço da humanidade toda, mas dos interesses particulares da classe que detém a propriedade dos meios de produção." (CORBISIER, 1980, p. 24). Remexendo nos escritos de Marx e Engels, Roland afirma que "[...] sendo as ideias dominantes as ideias da classe dominante, (...) o falso universalismo da ideologia dominante, na verdade particularista, traduz e mascara a realidade social, a luta de classes, a opressão e a espoliação da maioria pela minoria privilegiada". De plano, o Oráculo insiste não existir "[...] uma ciência e uma técnica burguesa, mas uma ciência e uma técnica a serviço da burguesia e de seus interesses privatistas." (CORBESIER, 1980, p. 24). Neste caso, Roland reporta-se, referencialmente, às ciências sociais, impropriamente chamadas humanas,

Cujo objeto é o próprio homem, e nas quais os juízos de realidade são inseparáveis dos juízos de valor, porque, nessas ciências a incidência ideológica é inevitável, tendo pleno sentido falar em uma economia burguesa, uma sociologia burguesa e mesmo uma filosofia burguesa. (CORBESIER, 1980, p. 25).

Mesmo enquadrado no aparelho de produção capitalista, ao contrário do técnico e do "cientista", consciência infeliz, o educador político é um subversivo em estado potencial, à medida que inexiste ciência sem crítica, sem contestação.

Observa ainda que:

Dilacerados pela contradição os intelectuais encontram-se diante do seguinte dilema: aceitam a ideologia dominante e podem mesmo contribuir para difundi-la, e, de má fé, mantêm o universal a serviço do particular, praticando a autocensura e declarando-se apolíticos, ideologicamente neutros, convertem-se, assim, como dizia Paul Nizan, em "cão de guarda" do sistema capitalista da exploração do homem pelo homem. (CORBISIER, 1980, p. 26).

Mas há outra possibilidade, uma segunda hipótese ou outro caminho, quando os intelectuais assumem a crítica do capital e começam a contestar a ideologia dominante, denunciando seu caráter de classe, recusam o papel de funcionário alienados da superestrutura, instrumentos a serviço de fins que não determinam, ou contribuem para determinar, porque lhes são impostos compulsoriamente; recusam ser uma espécie de "parafuso", ou "peça de engrenagem" da máquina capitalista e, por isto mesmo, decidem assumir a própria humanidade.

Como a escola não está à margem da vida, à margem da política, é pela mediação da política que ela (a escola) pode coadjuvar "a tomada de consciência" do caráter histórico político e temporal da existência humana. Em sendo assim, o processo pedagógico de aquisição de consciência revolucionária pode ser dividido, como aponta 
Roland, em três momentos: O primeiro momento é o da demonstração do significado do trabalho alienado, suas causas e seus determinantes. Neste caso, a alienação é total, "em si" e "para si". O segundo momento é quando o educador político suscita a necessidade da reflexão, da tomada de consciência como elemento indispensável à compreensão da realidade objetiva na qual o trabalhador não trabalha para si, mas para outrem (o capitalista). Amparado pele educação o trabalhador toma consciência dessa alienação que é superada no plano da consciência, mas não no plano da existência, pois as relações de produção continuam sendo capitalistas e nas quais continua o trabalhador a produzir para outrem! Enfim, o terceiro é aquele da luta revolucionária, no qual o trabalhador, teoricamente desalienado no plano da consciência, empreende, na prática, a luta pela desalienação no plano da existência, da realidade, "[...] que destrói, pela revolução, a alienação real." (CORBISIER, 1980, p. 27).

Para além da superação abstrata da alienação, "[...] a superação revolucionária é concreta porque é total, porque supera toda a alienação, tanto o seu momento teórico (consciência), quanto o seu momento prático, a realidade (a existência)" (CORBESIER, 1980, p. 28). Roland encerra suas considerações sobre os intelectuais com as seguintes palavras:

$\mathrm{O}$ verdadeiro intelectual é o intelectual verdadeiro, verdadeiro por ser o intelectual da verdade, e a verdade, como ensina Hegel, é a totalidade. (E) a partir do momento em que cientistas, técnicos e operários transcendem o particularismo da ideologia dominante e de sua situação funcional e têm acesso à consciência da totalidade, tornam-se todos por isso mesmo intelectuais ou filósofos - identificados por essa consciência e pelo projeto comum de libertação das classes oprimidas e espoliadas, pelo projeto de fazerem juntos, a revolução. (CORBESIER, 1980, p.28).

\section{O ocaso da velha toupeira}

Fala-se muito, ainda hoje, em educação "revolucionária" ou da "revolução" pela educação, quer dizer, transformação do capitalismo em socialismo por intermédio da educação. Convém registrar que nos idos dos anos 60 do século XX a palavra de ordem no seio da esquerda era a revolução. Meio século depois, a palavra de ordem entre nove de dez sindicalistas é a educação. Nesta quadra, o discurso sobre $10 \%$ do Produto Interno Bruto brasileiro destinado à educação pública soa como forma de se resolver as contradições do capitalismo.

Mas o que é, para Roland, a revolução? Não são poucos os pedagogos e intelectuais da educação que repetem ad nauseam que é possível fazer a revolução pela educação. Bem, neste caso, como explica Roland, "[...] a ideia de revolução está, pois, indissoluvelmente ligada à ideia de mudança ou de transformação, embora nem todas as mudanças ou transformações sejam revoluções." (CORBISIER, 1980, p. 31).

Encimado na tradição marxista que foi assumindo com vagar, mas com um destino certo, convencido, o Oráculo aponta a existência de duas modalidades fundamentais de transformação, em primeiro lugar, a transformação estrutural, ou seja, aquela que altera a estrutura profunda da sociedade, e, em segundo lugar, a transformação conjuntural ou acidental, isto é, aquela que apenas afeta os acidentes, sem tocar no que é essencial.

Para ser revolucionária a transformação deve consistir não apenas em modificações acidentais e quantitativas, mas, sobretudo, em alterações de caráter estrutural ou qualitativo. Na cidade do capital contemporânea, estribada na escravidão disfarçada de trabalho assalariado, as estruturas sociais têm por fundamento algo que se arrasta inalterado há séculos, a propriedade privada dos meios de produção e, consequentemente 
ou por extensão, todas as instituições jurídicas e políticas são decorrentes do regime de propriedade tão como é conhecido nos dias de hoje.

A cidade do capital é uma totalidade dinâmica e contraditória, nela é clara a vinculação entre a economia, a base econômica ou infraestrutura, as classes sociais e as instituições jurídicas, políticas e ideológicas ou superestrutura. E como assevera Roland, esta

\begin{abstract}
Vinculação não resulta de um compromisso moral, ou de um "contrato social", como imaginou Rousseau, mas é uma decorrência natural da divisão do trabalho. (...) Se a associação dos indivíduos no Estado, como observa Hegel, tivesse por base um contrato, quer dizer, a vontade arbitrária, a opinião e o interesse dos particulares, enquanto particulares, seria facultativo ser membro do Estado, e o contrato social poderia ser rompido a qualquer momento. A estrutura social, portanto, longe de ser um simples amontoado de membra disjecta é, ao contrário, um conjunto integrado, uma totalidade, cujos elementos constitutivos se acham todos, direta ou indiretamente, ligados uns aos outros. (CORBISIER, 1980, p. $33)$.
\end{abstract}

O que interessa é que tipo de mudança deve ser considerado revolucionário e que pode ser definido como mola propulsora do processo histórico. Certamente, não é a educação, mas a revolução a "[...] obstetra da história, e a metáfora nos permite observar, ainda uma vez, que o recurso à intervenção cirúrgica só se impõe quando os novos seres humanos não nascem espontaneamente, o único objetivo da intervenção sendo o de propiciar esse nascimento." (CORBESIER, 1980, p. 38).

Na contramão das revoluções francesa (1789), russa (1917), chinesa (1949) e cubana (1959), a suposta "revolução" brasileira (1964) não passou de um golpe de Estado, contrarrevolucionário, promovido por grupos de industriais, militares e burocratas como negação da revolução, e instituição de repressão, do arbítrio e da violência psíquica e física: negação da democracia (em seu sentido literal) e do Estado de direito (não burguês, mas popular).

Ao contrário do senso comum ou opinião pública, grosso modo, formada / imposta de cima para baixo, o filósofo deixa claro que:

Violência não é coextensiva(sic!) à ideia de revolução, pois assim como há movimentos armados e golpes de Estado sem que haja revolução, assim também, a revolução propriamente dita não consiste na luta armada e no derramamento de sangue, mas, na transformação estrutural da sociedade. A violência revolucionária não é original, mas derivada, consequência do que poderíamos chamar de violência conservadora. (CORBISIER, 1980, p. 42).

Violência conservadora, eu diria reacionária, que tem no Estado o fulcro do seu desenvolvimento e aplicação, ou seja, “[...] a complicada engrenagem da máquina burocrática, e os dispositivos armados, policiais e militares, não exprimem e representam senão os interesses das classes dominantes que, por serem dominantes, contra o parelho de Estado" (CORBESIER, 1980, p. 44). Como adverte Roland:

A violência conservadora está, pois, contida nas armas, de cujo fabrico e emprego o Estado detém o monopólio. É desnecessário observar que essa violência manifesta-se, irrompe, sempre que ocorre qualquer manifestação de inconformismo ou revolta que, a critério das autoridades 
(na sua quase totalidade comprometida com a classe dominante, seja porque com ela se identifica, seja porque foi por ela corrompida, cooptada, comprada por uns míseros reais ou em troca de uma prebenda ou sinecura), ameaça e põe em risco a "ordem" e a "segurança" do regime e das instituições, quer dizer, os interesses da classe dominante. (CORBISIER, 1980, p. 44).

Na cidade do capital é rotina banalizada “[...] a repressão violenta, o espaçamento, a prisão, a tortura e mesmo a morte daqueles que se insurgem contra o statu quo e reclamam liberdade e justiça" (CORBESIER, 1980, p. 45). Mas por que será que as revoluções, acontecidas na Europa, Ásia e América Latina, foram feitas sob a égide da violência? Porque a classe dominante, a burguesia, dona e beneficiária do poder econômico e político, emprega sempre na defesa de seus interesses e privilégios, o que chamamos de violência conservadora. Portanto, a violência revolucionária irrompe na história da humanidade como resultado da resistência oposta aos titulares que a exercem para conservar o statu quo, quer dizer, para manter seu poder sobre os meios de produção criando obstáculos às mudanças sociais necessárias e indispensáveis.

Noutra mão os revolucionários não negam para permanecer na negação, não destroem por destruir, mas para construir a liberdade das forças produtivas, criativas, e a permitir que a sociedade humana realize as transformações de estrutura exigidas pelo seu desenvolvimento.

Neste quadro relacional, admitida a escola oficial como parte do aparelho ideológico de Estado escolar, não interessa à classe dominante e ao Estado burguês que essa escola desvele a:

Estrutura social, baseada na espoliação do trabalho e na opressão que a garante. Não interessa à burguesia que se desvele a contradição (antagônica!) entre a democracia política e o capitalismo econômico, pois o diagnóstico dessa contradição envolve a denúncia e a condenação da injustiça fundamental em que assenta a sociedade burguesa. (CORBISIER, 1980, p. 57).

\section{Um imbróglio pedagógico}

Se for tautológica a noção de operário conservador, pelo simples fato que historicamente, ao contrário do burguês, este sim conservador por definição, seus interesses, interesses da classe oprimida extorquida, radicam "[...] na transformação das estruturas sociais, como explicar que essa classe faça, frequentemente, o jogo da casse dominantes, ou simplesmente deixem de organizar-se e lutar pela transformação social?" (CORBISIER, 1980, p. 62).

Por que será que a classe operária não toma o poder, em outras palavras, por que ela não "assalta o céu"? E por que será que ela não se organiza, não como uma espécie de órgão parlamentar, mas como grupo de trabalho com funções legislativas, executivas e judiciárias? Porque ela não se organiza, toma o poder e institui comissões militares, de finanças, de justiça, de segurança, do trabalho, da alimentação, da indústria e do comércio, do ensino e dos serviços públicos, no qual cada um dos representantes em cada comissão é responsável pelas políticas gerais da comunidade? Porque ela não se organiza e toma para si a adoção das mesmas medidas adotadas pela Comuna de Paris?

Medidas de incontornável caráter revolucionário, como: substituição do Exército permanente pelo armamento geral do povo; separação definitiva, sem meios termos, entre Igreja e Estado; laicização rigorosa da educação e fim da manutenção das escolas 
confessionais e privadas pelo Estado; redução da jornada de trabalho para quatro horas dias; eleições diretas para direções de fábricas; extinção do poder judiciário burguês - os juízes e os funcionários do judiciário serão escolhidos por eleição com sufrágio universal, admitindo-se a possibilidade de demiti-los, entre outras.

Como advoga Roland, a resposta não pode ser outra senão que a classe operária permanece resignada e passiva porque não tem consciência de classe, não ultrapassou o umbral da "classe em si", carecendo ainda de esclarecimento ideológico. Comporta-se, a classe, como se fosse um dado natural e não histórico "[...] que uns sejam ricos e outros sejam pobres, que uns vivam para trabalhar para que outros possam viver sem trabalhar" (CORBISIER, 1980, p. 62, os itálicos são meus).

Neste quadro que papel ou tarefa ou missão cumprem ou deveriam cumprir os intelectuais? Como preâmbulo à resposta, anoto alguns intelectuais apontados por Roland que, segundo ele, afrontaram o statu quo e tornaram o século XVI e o século XVII a alvorada da luta contra o obscurantismoi:

Nicolau Copérnico (1475-1543) que contestou a crença milenar e irracional do geocentrismo, isto é, da terra como centro do universo. Thomas Morus (1478-1535) que além de escrever desenha teoricamente a Utopia, um reino fictício numa ilha fictícia, foi condenando por sustentar que a raiz de todos os males sociais era a propriedade privada sobre os meios de produção. Giordano Bruno (1550-1600) foi um fervoroso e implacável adversário da escolástica e do aristotelismo. Francis Bacon (1561-1626) condenou o método puramente dedutivo e o da autoridade teológica e religiosa. Galileu Galileu (1564-1642) defendeu o sistema copernicano contra o sistema ptolomaico, foi denunciado pela inquisição como herético. Tomaso Campanela (1568-1639) sustentava de modo intransigente que só merecia o nome república (res publica, coisa de todos) as sociedades fundadas na comunidade de bens e de deveres. Johan Kepler (1571-1630) expulso do Seminário de Tubingen, por opiniões pouco ortodoxas. (CORBISIER, 1980, p. 70-73).

Mas qual o propósito de Roland ao citar esses intelectuais? Apenas deixar claro que no quadro apontado esses intelectuais não se comportavam como "[...] cães de guarda das classes dominantes, apologistas do statu quo e dos interesses estabelecidos, mas, ao contrário, os heróis e mártires da razão, da luta pela razão, contra as superstições, os dogmas, os preconceitos, os privilégios e as injustiça." (CORBESIER, 1980, p. 73).

Poder-se-ia citar ainda uma longa lista de intelectuais que no transcurso de suas vidas jamais foram cães de guarda das classes dominantes, cito como exemplos: JeanJacques Rousseau (1712-1778), Charles-Louis de Secondatt, Barão de La Brède e de Montesquieu (1689-1755), François Marie Arouet, Voltaire (1694-1778), Denis Diderot (1713-1784), Claude Adrien Helvetius (1715-1771), Jean le Rond D'Alembert (17171783), Paul Henri Thiery, Barão de Holbach (1723-1789) dentre outros que forneceram as bases filosóficas para os protagonistas da revolução francesa de 1789 liderada por Maximilien François Marie Isidore de Robespierre (1758-1794), Jean-Paul Marat (17431793), Honoré Gabriel Riqueti, conde de Mirabeau (1749- 1791), Lucie-Simplice-CamilleBenoist Desmoulins (1760-1794), Louis Antoine Léon de Saint-Just (1767-1794) e Georges Jacques Danton (1759- 1794) .

Roland chama atenção para um singelo e histórico fato, é verdade que os ideólogos ou les philosophes não fazem as revoluções, não participam do assalto e tomada do poder, no entanto, ainda que possa soar como paradoxal, sem eles, a revolução não é possível. Expõe o autor in comento que não é qualquer teoria que toca as massas, mas apenas a 
teoria que consegue exprimir ou traduzir as necessidades das massas, suas expectativas e reivindicações, se converterá em força material logo que penetre na consciência das massas. Não basta, portanto, que o pensamento procure a realidade, é necessário que a realidade procure o pensamento. Esta é a tarefa ou missão histórica dos intelectuais, pois se não existe revolução sem teoria da revolução, então, como ensina Lenin, cabe aos intelectuais "[...] criar a consciência revolucionária, condição prévia da transformação do mundo." (CORBISIER, 1980, p. 78).

\section{Uma idiossincrasia}

Os escritos de Roland, notadamente os realizados nos "anos de chumbo" e depois deles, são melhores compreendidos quando aliados às obras de Marx, Engels e Lenin nas quais o significado histórico de emancipação humana está diretamente vinculado à revolução como meio de edificação da sociedade comunista onde a consecução da emancipação da humanidade em geral permanece como o possível do vir a ser.

A crítica filosófica, sua crítica, deve ser radical, a crítica severa da sociedade capitalista na sua totalidade, não apenas da superestrutura ideológica (religiosa, filosófica e ética), jurídica e política, mas, sobretudo, da sua infraestrutura econômica. Garimpando a obra de Roland buscando encontrar as teses marxistas que destacam a revolução como processo ímpar à emancipação do proletariado foi um ponto chave do itinerário intelectual que percorro, ou seja, a postulação da auto-emancipação revolucionária do proletariado. Encontrei ulteriormente uma questão crucial, sem a qual o entendimento sobre o significado histórico da revolução está prejudicado.

Se Marx, Engels e Lenin construíram a crítica do modo capitalista de produção da existência no estreito convívio com os movimentos operários insurrecionais de seu tempo, a partir da classe operária, com ela e para ela, então não faz sentido separar Roland enquanto pensador austero e intransigente movido por uma ironia fina, do processo revolucionário.

Para ele, a revolução, a velha toupeira que corrói as bases da cidade do capital, tornou-se uma palavra démodé intencionalmente esquecida pela esquerda social democrata e, moto contínuo, suprimida do discurso e análise dos neomarxistas, marxistas de cátedra e marxólogos sobre a história recente deste país.

A teoria da revolução da tradição marxista é nos dias de hoje, mais um tema tributário ou apêndice de menos valor, como dizem os "críticos rigorosos" a serviço do capital, ultrapassado pela vitória e mundialização do capitalismo; substituída pelo messianismo irracional de uma educação supostamente libertária.

A contrario sensu dos críticos e de forma peremptória, a revolução como ato político significa a derrota do poder existente e a dissolução das velhas e viciadas relações de produção. Sem revolução não se edifica o modo comunista de produção da existência, mesmo porque, esse estágio da humanidade necessita do ato político revolucionário da mesma forma que necessita da dissolução do modo que como está estruturada a cidade do capital.

Do ponto de vista da totalidade a revolução social encerra o protesto dos operários e trabalhadores assalariados, dos extorquidos pelos capitalistas, contra suas vidas desumanizadas, portanto, o processo revolucionário está além do ponto de vista do individualismo pequeno burguês. A alma política da revolução consiste na tendência da classe carente de influência política superar o distanciamento histórico, imposto pela classe dominante, no tocante ao Estado e ao poder econômico.

Segundo a tradição marxista, a revolução não é um mero e extemporâneo apêndice insepulto no âmbito das considerações mais gerais sobre o desenvolvimento do capitalismo 
e sobre a transição para a sociedade comunista, mas processo imprescindível que une e dá sentido diferenciado à prática social como apologia da revolução. Não se pode desconsiderar que Roland, a propósito, quando se reporta à revolução o faz na estreita compreensão que os intelectuais:

Não brotam da terra como cogumelos, eles são frutos da sua época, do seu povo, cujas energias, tanto as mais sutis e preciosas como as menos visíveis, se exprimem nas idéias filosóficas. O espírito que constrói os sistemas filosóficos no cérebro dos filósofos é o mesmo que constrói os caminhos de ferro com as mãos dos trabalhadores. A filosofia não é exterior ao mundo. (MARX, 1990, p. 14).

Se a tradição marxista está correta na crítica à economia política e na difusão do ideário comunista no seio da classe operária e dos estudantes, então, ao adotá-la Roland, inevitavelmente e com certa frequência tornou-se alvo de agudos ataques dos intelectuais orgânicos da burguesia. Porém, passada a fase aguda desses ataques, vencida a ressaca, o filósofo saía mais fortalecido, mais temperado, e mais ativo, à medida que, para ele, não era possível ser um intelectual marxista sem realizar o labor teórico de acordo com as exigências da causa operária e da construção da sociedade comunista, sem propagar os resultados da teoria entre os operários ajudando-os na sua organização.

Esquerdistas, ex-comunistas e "guerrilheiros" penitentes não perdiam a ocasião e a oportunidade de se juntarem ao medíocre e farisaico coro da burguesia contra o filósofo que advogava da teoria da revolução socialista como fator da emancipação do proletariado; uma revolução tocada por sua própria responsabilidade e sob sua própria organização, atividade indispensável e preciosa bússola para o pensamento e prática social do proletariado.

Roland tinha claro que a existência material é o primado sob o qual se desenvolve a consciência, o subjetivo ou a subjetividade, por isto, considerava necessário salvar do descalabro do idealismo, exceção feita ao hegelianismo, a dialética consciente, para integrar a concepção materialista da natureza. Associando-se ao pensamento vivo de Marx citado por Lenin, faz a seguinte consideração sobre a natureza:

A natureza é a comprovação da dialética, e devemos dizer que nada há de definitivo, de absoluto, de sagrado para a filosofia dialética. Ela mostra a caducidade de todas as coisas e para ela nada mais existe senão o processo ininterrupto do surgir e do perecer, da ascensão sem fim do inferior para o superior, de que ela própria não é senão o simples reflexo no cérebro humano pensante. $\mathrm{O}$ modo de produção da vida material condiciona o processo da vida social, política e intelectual, em geral. A luta de classe é o motor dos acontecimentos. O que domina a sociedade capitalista é a produção de mercadorias. (...) Acelerando a substituição dos operários por máquinas e criando a riqueza num pólo e a miséria no outro, a acumulação do capital gera assim o chamado "exército de reserva do trabalho", o "excedente relativo" de operários ou "superpopulação capitalista". Marx conclui pela transformação inevitável da sociedade capitalista em sociedade socialista a partir única e exclusivamente da lei econômica do movimento da sociedade moderna. A socialização do trabalho (...) eis a principal base material para o advento inelutável do socialismo. O motor intelectual e moral, o agente físico desta transformação, é o proletariado, educado pelo próprio capitalismo. (LENIN, t. 1. 1977. p. 4-23). 
Não estou aqui a identificar a prática com o conhecimento, reflexo da realidade objetiva na consciência humana, mas apenas apontar que o conceito verdade é impensado sem o conceito reflexão vez que por "[...] verdade compreende-se a reflexão correta e adequada do mundo objetivo, verificada e confirmada pela prática." (LENIN, t. 18, 1983, p. 142). Quando se trabalha sobre o comunismo como projeto histórico de ultrapassagem do capitalismo, é preciso atentar para um simples fato: “[...] as ideias que tomam conta de nossas mentes, que conquistam nossos corações e aquelas que são forjadas por nossa consciência, são demônios sobre os quais os homens só podem triunfar entregando-se a eles." (MARX e ENGELS, 1979, p. 36).

Neste contexto, a educação política é indispensável para extirpar condutas e reminiscências ideológicas capitalistas e para a forja de novas normas de convivência social e a consciência socialista. É notório, hoje mais que dantes que a classe operária não consegue libertar-se a si mesmo sem suprimir as condições de vida que lhes são impostas pela economia política e não poderá suprimir tais condições sem erradicar as condições desumanas impostas pela cidade do capital.

Sintonizado com Marx, Engels e Lenin, Roland descobre a linha mestra sobre a qual aponta a revolução como processo social e político de destruição das bases concretas da cidade do capital, na qual o trabalho é atividade coletiva dirigida contra os trabalhadores, independente deles e que não lhes pertencem. Neste caso, o processo de embrutecimento da classe operária, em curso nos países capitalistas centrais e periféricos, não será resolvido pela educação formal oficial, púbica ou privada, apenas poderá ser interrompido por um movimento social prático, uma revolução.

A revolução como protesto violento do homem trabalhador contra a desumanização de sua vida. A alma política da revolução não poderia ser outra senão a tendência das classes carentes de influência política, superar seu isolamento no tocante ao Estado e ao poder econômico. Destarte, examinando com atenção a unidade entre o social e o político, consideramos que a revolução ao dissolver a velha sociedade é considerada uma revolução social. Neste caso, toda revolução ao derrotar o velho poder é, neste sentido, é uma revolução política.

A consciência de que uma revolução poderia ocorrer por meios pacíficos representa segundo Engels, “[...] uma impossibilidade e só a remoção pela violência das condições antinaturais existentes, a derrota radical da aristocracia nobiliária e industrial, melhoraria a situação material dos proletários" (ENGELS, in MARX; ENGELS, v. 2. 1981, p. 123).

Engels reporta ainda que a revolução social "[...] não pode ser evitada com nenhuma classe de medidas encaminhadas a fomentar o comércio e a indústria, o único meio de impedir tal revolução era a implantação e a preparação do sistema comunista" (ENGELS in MARX; ENGELS, v. 2, 1981, p. 256). Engels descortina ainda que o fenômeno da sociedade capitalista que transforma cada homem em inimigo dos demais. Segundo ele, uma economia política caótica e desorganizada teria como consequência "desastrosos resultados para a sociedade; a desordem que lhe serve de base e o abandono do bem estar verdadeiro e geral se manifestarão, mais ou cedo ou mais tarde, de um modo escandaloso" (ENGELS in MARX; ENGELS, v. 2, 1981, p. 263).

Segundo a tradição marxista, a revolução é completamente distinta das revoluções burguesas conhecidas, à medida que ela não "será dirigida contra a propriedade do monopólio, mas contra o monopólio da propriedade", a revolução social é a "guerra aberta dos pobres contra os ricos" (ENGELS in MARX; ENGELS, v. 2, 1981, p. 263). Uma guerra com envergadura para se opor aberta e sem recato a todas as causas que nos conflitos anteriores permaneceram veladas e ocultas. A revolução em questão tem um cariz, uma qualidade distintiva mais violenta e mais sangrenta que as anteriores. Nela as forças rebeladas, diferentemente das anteriores, extirparão o mal pela raiz, isto é, atacarão 
as causas reais da pobreza, da miséria, da ignorância e do crime organizado, levando ao fim e ao cabo uma verdadeira revolução social.

$\mathrm{Na}$ magistral obra $A$ situação da classe operária na Inglaterra, Engels faz um terrível relato da situação real dos operários ingleses do século XIX que, guardadas as proporções, permanece na hodierna cidade do capital em pleno século XXI: "[...] os famintos não têm reservas para resistir aos resfriados e infecções, que irremediavelmente o levam a tumba" (ENGELS in MARX; ENGELS, v. 2, 1981, p. 304).

Se no século XIX os operários britânicos chamavam este acontecimento de "assassinato social" e, mais ainda, acusavam a sociedade de cometer todas as horas este tipo de crime, no Brasil do século XXI que nome deveria receber este tipo de acontecimento, não seria por acaso "genocídio social" decorrente do mesmo modo de produção praticado na Inglaterra do século XIX?

Mutatis mutandis, o quadro retratado por Engels é verossímil ao quadro brasileiro à medida que nos bairros pobres por todos os lados o que se vê são montões de lixo e de escória, diante das portas dos casebres líquidos parados, formando charcos pestilentos. Nos bairros insalubres, grosso modo, chamados favelas, "vivem" pobres miseráveis, trabalhadores mal pagos, misturados com ladrões e prostitutas. Permanecendo nestas condições, não têm outra opção senão (1) morrer de fome, (2) aceitar esmolas do governo via programa "fome zero", (3) fazer a revolução. Lamentavelmente, há aqueles que preferem enfrentar a policia após pequenos e médios furtos, posto que os grandes furtos praticados na calada da noite e com a assistência incontornável da caneta estão reservados aos bandidos de colarinho branco.

Como decorrência da gigantesca centralização do capital em poucas mãos, o operariado e os trabalhadores assalariados logo compreenderão a necessidade histórica de expropriar as ilhotas de milionários. Em outras palavras, chegará o momento em que eles se darão "[...] conta de quão fácil será derrotar a ordem social existente, neste momento estará aberto o caminho para a revolução. A guerra dos pobres contra os ricos será mais sangrenta como jamais se conheceu" (ENGELS, v. 2, 1981, p. 305).

Nada aplacará sua ira. E a nomeação da "aristocracia operária" para administrar os interesses da burguesia e minimizar os conflitos sociais, apenas postergará o processo revolucionário, mas não o deterão. Na verdade, a nova gironda será devorada, como a outra, no transcurso da Bastilha operária.

\section{A crítica das armas}

É recorrente a tese posta pelos revisionistas sobre a inadequação da revolução como método de transformação da realidade. Em outras palavras, a revolução foi uma necessidade nos séculos passados, mas no século presente ela estaria ultrapassada em virtude das mudanças positivas ocorridas no do desenvolvimento sustentável ${ }^{\text {ii }}$ do capitalismo.

Contrariando a tese revisionista supracitada a teoria da revolução ainda suscita na burguesia hostilidade incomensurável que vê nessa teoria uma espécie de seita perniciosa e um método arbitrário não democrático. Na verdade, o mesmo método por ela utilizado para destronar a monarquia e levar o monarca ao cadafalso, portanto, nada mais hipócrita. E não se poderia esperar outra atitude da burguesia e dos seus "cães de guarda" (os cientistas sociais, os filósofos e a quase totalidade dos intelectuais), pois na cidade do capital não há ciência social imparcial e nem intelectual neutro.

A perspectiva de alcançar a emancipação política da classe operária sem a revolução é, em primeiro lugar, uma deformação praticada contra o marxismo, em segundo lugar, é recortar a realidade que insiste em não ser recortada, pois a teoria do recorte, na 
prática, é perigosa à compreensão da realidade recortada. Sob o recorte proclama-se a suposta existência de incoerência entre o sonho da utopia proclamada - a sociedade sem classes, o comunismo - e o meio predicado, a revolução socialista como exacerbação da luta de classes.

O recorte oculta a inadequação histórica do capitalismo aos interesses e demandas dos operários e trabalhadores assalariados. E mais, o recorte escamoteia a imprescindibilidade da revolução proletária socialista como fator indispensável à débâcle definitiva do capitalismo. Mais ainda: sintonizada com a ideologia neoliberal, a teoria do recorte nega a necessidade da revolução como primeiro passo à edificação do modo comunista de produção da existência.

Com um acentuado ranço reacionário a teoria do recorte, ao negar e discrepar da realidade / do todo social, procura ocultar que o marxismo é a dialética da filosofia das luzes ou a filosofia das luzes como dialética, ultrapassando-a, ou seja, pelo método dialético supera os estreitos limites do materialismo do século XVIII que o desenvolvimento das ciências, à época, tornara inevitável.

O marxismo (e o seu método de transformação da realidade, a revolução) é herdeiro e continuador do Iluminismo porque não existe outra concepção científica da história que não seja o materialismo histórico a estender os princípios do materialismo dialético ao estudo rigoroso da vida social, ao estudo do desenvolvimento das sociedades.

Não se trata aqui de uma utopia antecipada de um futuro conhecido, mas a filosofia da história a decifrar-lhes os fatos, descobrir-lhes seu sentido, uma espécie de fio de Ariadne que, sem nos dispensar da análise sistemática de cada período histórico, nos permite discernir uma orientação correta sobre os acontecimentos.

Na Contribuição a Crítica da Filosofia do Direito de Hegel, Marx explica que a filosofia deve descer à terra, prolongar a crítica do céu pela crítica social, "[...] a crítica do céu transforma-se deste modo em crítica da terra, a crítica da religião em crítica do direito, e a crítica da teologia em crítica da política." (MARX, 1989. p. 78). A crítica, enfatiza ele, "[...] não é fim em si, mas apenas um meio; a indignação é o seu modo essencial de sentimento, e a denúncia a sua principal tarefa" (MARX, 1989, p. 80). A tarefa da crítica, nesta perspectiva, tem por

Imperativo categórico derrubar todas as condições em que o homem [operário] surge como um ser humilhado, escravizado, abandonado, desprezível - condições que, no dizer dele, dificilmente se exprimirão melhor que na exclamação de um francês, por altura da proposta de imposto sobre cães: Pobres cães! Já vos querem tratar como homens! (MARX, 1989, p. 86).

Em sendo assim, a revolução é compreendida historicamente como necessária à supressão do modo de produção capitalista da existência e para fazer com que os operários e trabalhadores assalariados do campo e das cidades passem do reino da necessidade ao reino da liberdade. Contrariando o senso comum da intelligentsia, incluindo os esquerdistas da ordem, não estou aqui a predicar uma cunha teorética a separar o indivíduo da classe social, o homem da história, o cientista do moralista, o homem culto do homem ignorante, o burguês do operário. Mesmo porque encimado no marxismo estas contradições foram superadas. Mais do que uma simples cunha, a obra de Roland é uma espécie de amalgama dialética que resgata e reafirma a indissociabilidade entre teoria e prática, restabelecendo a relação do pensamento com a realidade.

Calçado na obra de Marx, Engels e Lenin, Corbesier (1980) recoloca a filosofia na luta política e devolve aos comunistas sua verdadeira função original de organizadores do código de conduta revolucionário no qual estão estabelecidas a unidade e a dignidade do 
operário, configurando-se, ainda, como empreitada prática e teórica, ação e crítica intransigente da extorsão exercida pelos capitalistas sobre o trabalho alheio. Penso que sua obra quando se apropria do conhecimento produzido pelo que de melhor tem a humanidade, torna-se mais percuciente ao analisar o capitalismo à medida que o faz despindo suas contradições e suas recidivas crises cíclicas. Para este autor, o século XXI, no qual viveu apenas quase cinco anos (sua última respiração aconteceu em fevereiro de 2005), representa a possibilidade concreta (1) da revolução socialista, (2) do fim da exploração do homem pelo homem, exploração capitalista, (3) da emancipação dos trabalhadores, (4) e da irrefreável edificação da sociedade comunista.

A análise recente da realidade mundial, agora sob a influência decisiva e anacrônica da ideologia neoliberal, confirma a profundidade científica da obra desse estudioso à medida que assevera como único o materialismo histórico na explicação da amplitude da história humana. Sendo as condições de vida do proletariado hodierno, claramente piores que em 1845, o resgate da revolução parece ser iminente como único caminho à superação da depauperação econômica e social dos trabalhadores em escala mundial. Nas atuais circunstâncias em "deitada em berço esplêndido, ao som do mar e à luz do céu profundo" dorme a nação brasileira, a precariedade, a decomposição estrutural, a delinquência da superestrutura jurídica e política, às quais são submetidos os trabalhadores em geral, os poucos que escapam constituem uma parte relativamente pequena do enorme exército industrial.

Sem me arriscar a deixar a trilha aberta por Corbesier (1980), entendo que os interesses essenciais e decisivos da classe operária só podem ser satisfeitos, grosso modo, como decorrência de transformações sociais radicais e que os interesses econômicos fundamentais da classe só podem ser satisfeitos por intermédio da revolução política que substitui a ditadura burguesa pela ditadura do proletariado

Pensar a escola na cidade do capital como lócus de afirmação da teoria revolucionária e, sobretudo, do exercício da prática revolucionária é uma forma pueril de pensar a política maior deste país. Não é salutar esquecer as lições da história, mormente aquelas que de modo claro e insofismável demonstram que quando uma classe social pretende tomar da outra que antes dela era dona dos meios de produção se vê obrigada, para realizar suas demandas e fins, a pautar seus interesses como sendo o interesse coletivo, ou seja, o interesse de todos os membros dessa sociedade. A classe que pretende ser dominante é obrigada a exprimir seus interesses idealmente, isto é, dar aos seus pensamentos a forma de universalidade, apresentando-os como os únicos racionais e universalmente válidos.

A radicalidade analítica de Roland, associado à de outros autores reconhecidamente revolucionários, me fez compreender e admitir como necessária e exequível a socialização, isto é, a expropriação dos meios de produção, e a socialização da produção, da distribuição e do consumo de bens produzidos como valor de uso. Compreendi ainda como necessário participar da formação da consciência crítica da totalidade ou da consciência de classe que vai além da aparência, derruba máscaras e ilusões pagando o preço da crítica, da luta, da transgressão, da desobediência rumo à revolução. Não posso, pois, permanecer na ilusão pequeno-burguesa na qual a educação teorética seria suficiente para reparar erros e mazelas inerentes ao modo capitalista de produção da existência.

Para além da ilusão pequeno-burguesa entendi que apenas a revolução socialista conduzida pelo proletariado tem a força necessária à derrubada da classe dominante e à total anulação das classes sociais. Eis que a revolução socialista representa o concreto histórico, o socialmente imprescindível para a queda da burguesia, o desfazer-se do lixo autoritário acumulado na longa vida das sociedades de classes e a assunção de uma nova formação social comunitária, a sociedade comunista. 
A organização da prática revolucionária deve ser enfocada na educação em geral e no ensino escolar em particular como necessidade histórica e principal tarefa da classe operária, pois apenas pela prática revolucionária é possível educar os homens e as mulheres livres de amanhã.

$\mathrm{Na}$ contramão da cidadania parcelar observada na cidade do capital, a humanização do homem operário que corresponde à cidadania plena só pode ser levada ao fim e ao cabo pela expropriação dos expropriadores, base fática da edificação de uma nova sociedade.

A revolução não pode prescindir dos seguintes elementos materiais historicamente construídos, as forças produtivas existentes e a formação da massa revolucionária que se revoltará, não apenas contra as condições particulares da sociedade existente, mas, sobretudo, contra a própria produção da vida vigente, indigente, contra a atividade social e econômica total que lhe é imposta.

É falsa a proclamação da revolução como parteira da história quando as condições objetivas inexistem. Mais falsa ainda é afirmar as condições de existência na cidade do capital (observadas neste país: desemprego, fome, miséria, brutalidade máxima e explícita, corrupção, gatunagem, malversação do erário, entre outras), como normalidades nãomodificáveis, perenes, imutáveis, eternas, diante das quais os desesperados antevêem apenas a impossibilidade de sua erradicação por serem, dizem, características naturais e não históricas.

A sorte é que milhões de homens e mulheres, mundo afora, e em processo de humanização, pensam de modo oposto, e irão provar no devido tempo, quando puserem sua existência em harmonia com sua consciência de um modo prático, por meio da revolução. Trata-se, pois de revolucionar o mundo existente, de atacar e transformar, na prática, o estado de coisas existente. Nesta seara nas quais as coisas já foram tão longe em demasia, os indivíduos devem apropriar-se da totalidade existente das forças produtivas para assegurar e transformar sua existência insuportável, em existência plena de realizações.

Por suposto, a expropriação dos expropriadores, volto a insistir, só poderá ser realizada por intermédio da revolução que desenvolva o caráter universal e a energia do proletariado necessária para a realização dessa expropriação / apropriação.

Todavia, é necessária a formação da consciência comunista oriunda da transformação sorrateira, mas contínua e em larga escala, dos homens e mulheres educados e temperados pelo capital em coveiros das quadrilhas que controlam a economia política neste país. Discursos em contrário são reacionários à espera que a terra se faça céu e o céu se faça terra, para então, brilhar eternamente, em meio a celestial harmonia, a alegria e a felicidade.

\section{Quem ensina o alfabeto ao professor?}

Não me resta dúvida, é a revolução e não o trabalho e nem a educação (embora do trabalho e da educação não seja possível prescindir) o instrumento capaz de fazer o proletariado acessar o acervo cultural produzido e acumulado historicamente pela humanidade e sem o qual a humanização dos trabalhadores será apenas mais uma categoria discursiva, vazia, engodo retórico inescrupuloso.

Mais que dantes está claro e cristalino que a formação de consciências críticas necessárias à superação das concepções místico-religiosas dóceis à burguesia, não pode prescindir da crítica ácida aos fundamentos da imaterialidade nos quais o homem se nega a si próprio e à sua independência.

A crítica da ordem social prevalente que, ao longo dos anos vem forçando a classe operária a renunciar a uma vida digna e a subordinar-se ao capital, é um aspecto 
incontornável da trajetória de luta para se alcançar a almejada emancipação política de todos os homens e mulheres e a construção do modo comunista de produção da existência. $\mathrm{O}$ intelectual marxista para ser útil ao proletariado e aos trabalhadores assalariados deve distinguir casos "concretos" que, à luz da razão, representam a pura e inadmissível expressão do alpinismo social.

Ao final da leitura do livro de Corbesier in comento, penso que a suposta crise do marxismo me fez debruçar-me mais atento ainda sobre a obra de Marx, Engels e Lenin, notadamente em virtude dos ataques das teorias novidadeiras hegemônicas que negam à teoria revolucionária o direito de existência, condenando-a, tarde ou cedo, à bancarrota política. Mais atento é preciso adotar de modo resoluto uma posição rigorosamente determinada na luta da classe operária contra a classe dos capitalistas.

Com o livro Filosofia e Crítica Radical, aprendi com Corbesier a ler o "alfabeto" da política e da filosofia e com isto pude perceber mais e melhor que o marxismo se robustece nas crises com a prática da classe operária e dos trabalhadores assalariados, e longe de pretender ensiná-los formas de luta, assumo a linha de ação de seguir adiante com eles até a vitória!

Há caminhos sendo percorridos que justificam a crítica em construção: reafirmar a perspectiva da totalidade como característica do marxismo, enquanto paradigma oposto ao positivismo e à deformação científica praticada por intelectuais preocupados em descontaminar a educação dos agentes patogênicos políticos e ideológicos.

Neste quadro, cabe encetar a crítica acerba para ratificar a irredutibilidade da realidade a momentos de uma prática sem teoria ou de uma teoria sem prática, calcadas no professoralismo, na erudição da retórica vazia e na ignorância sobre o particular inexistente senão à medida que se vincula ao geral. Cabe ainda tornar evidente que a força de trabalho coletiva extorquida e desumanizada é meio secular a colocar em cheque a pregação dos neoliberais sobre a melhora da qualidade de vida do proletariado ocultando sua hedionda espoliação nas relações de produção capitalistas.

A crítica edificada por Roland representa uma indispensável contribuição à desobstrução da retórica positivista e da pragmática hegemônica no interior da universidade pública brasileira que um dia foi pensado como espaço alternativo possível à deslegitimação da ordem burguesa e lócus de reconstrução do real que se revela como história em construção.

Entretanto, há vulgares charlatães que acreditam no espírito santo, são impostores piedosos, finórios místicos, inescrupulosos na escolha dos meios, dado que a sua própria pessoa se identifica intimamente com o fim sagrado que têm em vista. Ademais, acreditam em inspirações, revelações, salvadores da pátria e de acordo com o seu grau de cultura, esta crença irracional assume formas primitivas e, algumas vezes, formas sofisticadas, e segundo a dose de energia que possuem, seu temperamento, sua posição de classe, acabam adotando posições ativas ou passivas, mas desconexas em relação à crença miraculosa, tomando dois caminhos: o de pastor miraculoso ou o de ovelha baladora. Refletindo sobre a crítica de Roland, parece que as coisas pouco mudaram, à medida que a grande maioria dos intelectuais o movimento que transforma a realidade só tem existência na cabeça de um salva pátria. Neste caso, o destino da humanidade dependeria da cabeça predestinada que possui a sabedoria e se arrisca ser ferido por uma pedra realista, antes de ter feito suas revelações.

Nesta perspectiva a evolução histórica desses pastores miraculosos e das ovelhas balantes, está reduzida a um conjunto de ideias abstratas sobre o desenvolvimento das sociedades, da mesma forma como se formaram nas cabeças dos teólogos e filósofos idealistas da atualidade. Diante deste fato, arguem ser necessária uma cabeça sagrada que lidere as demais cabeças filosóficas e teológicas, sendo que essa sutil cabeça de fila 
representará no plano especulativo a unidade das cabeças obtusas - é o eleito, o escolhido, o operário salva pátria.

Os intelectuais pequenos burgueses procuram persuadir os outros de que o mundo do qual extraem seus alimentos não existe sem os seus sagrados excrementos. Quando essa extravagância teórica sai do plano da idealidade e passa para o plano prático, o seu caráter pernicioso se manifesta com o gosto clerical pela dominação, fanatismo religioso, charlatanismo, hipocrisia, piedosa impostura dos revisionistas. O milagre é posto como tábua de salvação que conduz do reino das ideias à prática conservadora. Reacionária!

Sem embargo, procuram reduzir as teorias socialistas antigas à sua expressão mais abstrata, mais deformada, mais insípida e mais geral, e segundo eles, nessas teorias não há uma única ideia original. Mesmo a forma e o estilo nada têm de original. Os intelectuais acadêmicos se tornaram reacionários ad majorem dei gloriam. ${ }^{\text {iii }}$

Esta redução ad absurdum mascara a diferença fulcral entre modos de produção antitéticos, o modo de produção capitalista e o modo de produção comunista, além de adulterar a tese na qual a individualidade biológica como direito inalienável dos seres humanos, não condiciona, não determina, portanto, não justifica os privilégios e o usufruto das riquezas pela minoria.

\section{A crítica extraída da crítica do Programa de Gotha}

O princípio pelo qual o modo de produção comunista se distingue do modo de produção capitalista, sob todas as suas formas, tem por base objetiva a natureza do homem, ou seja, as diferentes valências físicas e as capacidades intelectuais (biomecânicas e neurofisiológicas) não condicionam de forma alguma a distinção e a dessemelhança das necessidades físicas, intelectuais e sociais.

$\mathrm{Na}$ cidade do capital o direito igual é, em princípio, o direito burguês, e ainda que o princípio e a prática não estejam claramente em conflito, o direito igual continua atordoado pela limitação burguesa. Evidente que alguns indivíduos são "superiores", física e intelectualmente, a outros, por isto mesmo, no mesmo lapso tempo, podem trabalhar mais tempo ou produzir mais no mesmo tempo. O direito igual é, portanto, um direito desigual para trabalho desigual. (MARX, t. 3, 1981).

Se nesta questão não se reconhece a distinção de classe, posto que cada indivíduo é visto apenas como operário, assim sendo apenas se reconhece, tacitamente, as desiguais aptidões dos indivíduos e, por conseguinte, desigual capacidade de rendimento que é, portanto, como todo direito, o direito da desigualdade.

O direito só pode consistir, por natureza, na aplicação de uma medida igual, mas se os indivíduos são, por natureza, desiguais (não seriam indivíduos se não fossem desiguais) eles só podem ser medidos por uma mesma medida sempre e quando sejam considerados sob um mesmo ponto de vista, isto é, sob um aspecto determinado, como operários. E não se veja neles outra coisa senão apenas isto, prescinda-se de tudo o mais.

Mas se uns operários são casados e outros não, uns têm mais filhos que outros, e se para trabalho igual haverá participação igual no fundo social de consumo, então fica claro que uns obterão de fato mais do que outros, de modo que uns tornar-se-ão mais ricos do que outros. Para evitar este inconveniente, o direito não teria que ser igual, mas necessariamente desigual.

Este defeito é inevitável na primeira fase da sociedade comunista, no socialismo, e permanecerá enquanto tal à medida que perdurar a etapa primeira desta nova sociedade, tal como brotou na sociedade capitalista, sua erradicação obedecerá a um longo e doloroso processo. É preciso compreender que o direito jamais será superior à estrutura econômica e ao desenvolvimento cultural e social da sociedade por ela determinado. 


\section{Enfim}

Nunca é por demais assinalar que apenas na sociedade comunista, notadamente quando não mais houver a subordinação escrava dos indivíduos à divisão do trabalho e, com ela, o contraste entre trabalho intelectual e trabalho manual; quando o trabalho não for somente um meio de vida, mas a primeira necessidade vital; quando com $\mathrm{o}$ desenvolvimento dos indivíduos em todos os seus aspectos, crescerem também as forças produtivas e jorrarem em caudais os mananciais da riqueza coletiva; só então será possível a ultrapassagem total do estreito horizonte do direito burguês e a nova sociedade poderá inscrever definitivamente em sua bandeira: "[...] de cada qual, segundo sua capacidade; a cada qual, segundo suas necessidades." (MARX, t. 3, 1981, p. 15).

Mas se na cidade do capital, confirmando a crítica de Marx, os operários e trabalhadores assalariados não usufruem da riqueza e dos bens produzidos "segundo suas necessidades", é possível, então, entender que as diferenças no trabalho não justificam desigualdades e privilégios no campo da fortuna e do usufruto.

$\mathrm{O}$ argumento na direção oposta ao justificar as desigualdades econômicas e sociais entre o proletariado e o patronato, apenas procura fazer com a sociedade reconheça que as diferenças entre trabalho manual e trabalho intelectual, diferenças de classe, e justifiquem as diferenças de felicidade calçada no usufruto, mérito e prazer, e que à medida que cada um determina por si próprio e para si próprio tudo o que necessita para ser feliz, por consequência, o patronato se vê no direito de reivindicar uma vida melhor do que o vulgar operário.

Sem rodeios e sem o menor constrangimento, os apologistas da cidade do capital que são muitos e loquazes, não reconhecem ou ignoram que a imparcialidade do direito burguês permite a cada um dormir onde quiser ou onde bem lhe aprouver, no quarto de hotel cinco estrelas ou sobre papelão debaixo de um viaduto urbano, corolário compulsório do modus vivendi de parte significativa dos trabalhadores e operários brasileiros.

Para encerrar, em sede doutrinária esta tese representa o véu místico atrás do qual se esconde a vontade de usufruto de todos os hipócritas, a desculpa que mascara a torpeza das ignomínias do capitalismo e fonte de numerosos desregramentos da sociedade contemporânea.

\section{Referências}

BOBBIO, N. Os intelectuais e o poder. São Paulo: Unesp, 1997.

CORBISIER, R. Os intelectuais e a revolução. Rio de Janeiro: Avenir, 1980.

ENGELS, F. Cartas de Inglaterra. In Escritos de Juventude. MARX, K y ENGELS, F. Obras Fundamentais, v. 2. México: Fundo de Cultura Econômica, 1981.

ENGELS, F. Dois discursos em Elberfeld. In Escritos da Juventude. MARX, K. e ENGELS, F. Obras Fundamentais, v. 2. México: Fundo de Cultura Econômica, 1981.

ENGELS, F. Rápidos avanços do comunismo na Alemanha. In Escritos da Juventude. MARX, K e ENGELS, F. Obras Fundamentais, v. 2. México: Fundo de Cultura Econômica, 1981a.

ENGELS, F. Situação da classe operária na Inglaterra. In Escritos da Juventude. MARX, K. e ENGELS, F. Obras Fundamentais, v. 2. México: Fundo de Cultura Econômica, 1981b.

FEUERBACH, L. A essência do cristianismo - prefácio da segunda edição. Campinas: Papirus, 1986. 
LENIN, V. I. Karl Marx. Obras Escolhidas em três tomos, t. 1. Lisboa: "Avante!" / Moscou: Progresso, 1977.

LENIN, V. I. Materialismo e empiriocriticismo. Obras Completas em cinquenta e cinco tomos, t. 18. $5^{\text {a }}$ ed. Moscou: Progresso, 1983.

LENIN, V. I. Obras Completas em cinquenta e cinco tomos - t. 5. 5. ed. Moscou: Progresso, 1981.

MARX, K. Crítica do programa de Gotha. In MARX, K. e ENGELS, F. Obras Escolhidas em três tomos, t. 3. Moscou: Progresso, 1981.

MARX, K. Contribuição à Crítica da Economia Política. São Paulo: Martins Fontes, 1983.

MARX, K. Capítulo VI inédito de o capital: resultados do processo de produção imediata. São Paulo: Moraes, 1985.

MARX, K. Manuscritos econômicos - filosóficos. Lisboa: Edições 70, 1989.

MARX, K. Textos filosóficos. São Paulo: Mandacaru, 1990.

MARX, K. e ENGELS, F. A ideologia alemã [Feuerbach]. São Paulo: Ciências Humanas, 1979.

PETRAS, J. Ensaios contra a ordem. São Paulo: Página Aberta, 1995.

SARTRE, J. P. Em defesa dos intelectuais. São Paulo: Ática, 1994.

\footnotetext{
${ }^{\mathrm{i}} \mathrm{O}$ obscurantismo na Idade Média foi a atitude assumida pelo clero e a monarquia contra a disseminação da cultura entre os escravos e os servos de gleba, as classes sociais mais baixas das sociedades feudais. $\mathrm{Na}$ verdade, longe de ter sido exaurido o obscurantismo continua na Idade Moderna como prática usual das classes dominantes que se acreditam superiores cujo objetivo é manter os operários e trabalhadores assalariados, ao longo dos anos, na mais dantesca e obscena obscuridade.

ii Sustentável é tudo o que pode ser sustentado, ou seja, passível de sustentação ou abastecimento renovado do conjunto das substâncias necessárias à conservação da vida. Contudo, apesar dos discursos oficiais afirmarem ad nauseam que o atual estágio de desenvolvimento do capitalismo no Brasil é sustentável, na prática, não é isto o que ocorre, vide o desmatamento indiscriminado cujos resultados são (1) a extinção da fauna, (2) a destruição flora e (3) a redução da capacidade reprodutiva da natureza que em seus estertores clama por socorro diante da inclemência dos donos do capital e da terra e do crime de lesa-pátria dos políticos profissionais.

iii Para a maior glória de deus.
}

Recebido em: $\quad 31 / 08 / 11$

Aprovado em: $\quad 07 / 11 / 11$ 